\title{
ЯКІСТЬ ОСВІТИ ЯК СУЧАСНА ПАРАДИГМА ПІДГОТОВКИ МАЙБУТНІХ ФАХІВЦІВ ЗА СПЕЦІАЛЬНІСТЮ «ДОШКІЛЬНА ОСВІТА»
}

Іншаков А. С. Якість освіти як сучасна парадигма підготовки майбутніх фахівців за спеціальністю «Дошкільна освіта».

Статтю присвячено питанням підвищення успішності та якості освіти у професійній підготовці вихователів дошкільних навчальних закладів у курсі «Сучасна українська мова 3 практикумом». Запропонована система роботи та форми контролю сприятимуть формуванню необхідних для вихователя мовленнєвих умінь і навичок.

Ключові слова: якість освіти, дошкільна освіта, узагальнення та систематизація знань, рівень успішності, змістовий модуль, формування умінь і навичок, форми контролю успішності.

Иншаков А. Е. Качество образования как современная парадигма подготовки будущих специалистов за специальностью «Дошкольное образование».

Статья посвящена вопросам повышения успеваемости и качества образования в профессиональной подготовке воспитателей дошкольных учебных заведений в курсе «Современный украинский язык с практикумом». Предложенная система работы и формы контроля помогут формированию необходимых для воспитателя языковых умений и навыков.

Ключевые слова: качество образования, дошкольное образование, обобщение и систематизация знаний, уровень успеваемости, содержательный модуль, формирование умений и навыков, формы контроля успеваемости.

Inshakov A. Ye. The quality of education as a modern paradigm of preparing future specialists for speciality "Preschool Education".

The article is devoted to issues concerning improving grades and the quality of education while training preschool teachers in the course "The modern Ukrainian language workshop". The suggested system of work and forms of control will help to form language skills that are necessary for a teacher.

Key words: the quality of education, preschool education, generalization and systematization of knowledge, performance level, information-packed module, the formation of abilities and skills, forms of control performance.

Якість вищої освіти - одна 3 ключових проблем вищої школи. Вона визначається як багатоаспектне поняття. Із входженням України до єдиного Європейського освітнього простору, переходом до Болонської освітньої системи актуальним $\epsilon$ питання якості освіти.

У 1998 р. в Ліоні Міжнародна конференція з проблем вищої освіти у Всесвітній декларації акцентувала увагу на якості вищої освіти.

Науковець О. Волков, аналізуючи зміст якості вищої освіти, визначає організаційні, методичні й технологічні чинники підготовки фахівців. Низку 3 них оцінюють під час атестації та акредитації вишів. Три групи чинників, що впливають на якість освіти, визначає О. Зінченко. Зовнішні та внутрішні чинники аналізує С. Мохначов. Чинники якості освітнього процесу на вході, виході та рівні зворотного зв'язку аналізує О. Лещинський. Окремі компоненти забезпечення якості вищої освіти розглядає В. Вікторов. 
Як бачимо, якість освіти постійно $є$ колом наукових пошуків багатьох дослідників. Низка питань потребує свого розв'язання. Цим і зумовлена тема статті та iii актуальність.

Mema cmammi: обгрунтувати навчально-методичне забезпечення організації контролю навчальних досягнень студентів ВПНЗ у процесі вивчення дисципліни «Сучасна українська мова $з$ практикумом».

Якість підготовки фахівців на денній формі навчання спеціальності «дошкільна освіта» передбачає систему навчальних курсів.

Дисципліна «Сучасна українська мова 3 практикумом» для денної форми навчання розрахована на 7 кредитів, 6 модулів. Загальна кількість годин - 252, із них 54 год. лекцій, 72 год. семінарських занять, самостійна робота студентів - 126 год. Передбачено індивідуальне завдання: захист проекту «Культура мовлення вихователя дошкільного закладу».

Курс «Сучасна українська мова 3 практикумом», що викладається студентам спеціальності «дошкільна освіта», читається впродовж першого (I, II семестри) та другого (III семестр) курсів. Він покликаний навчити майбутніх вихователів вільно користуватися всіма багатствами рідної мови у процесі педагогічного спілкування. Укладена програма 3 курсу «Сучасна українська мова 3 практикумом» відповідає поставленим завданням. Тематичне планування охоплює найважливіші питання вивчення сучасної української літературної мови, типологію мовних норм, характеристику найважливіших лінгвістичних понять. Водночас студенти мають засвоїти теоретичні положення, що сприяють розвитку їхнього мислення, зв'язного мовлення, які в подальшій роботі допоможуть удосконалювати мовленнєву діяльність дітей.

Мета викладання дисципліни полягає в забезпеченні студентів знаннями 3 сучасної української літературної мови, закріпленні, розширенні й систематизації знань про нормативність мови й мовлення, принципів системності мови.

Практичні заняття розраховані на те, щоб сформувати базові, основоположні поняття у студентів із питань функціонування сучасної української літературної мови в галузі фонетики й фонології, орфоепії, графіки й орфографії, морфології та синтаксису, уміння спілкуватися за допомогою живого слова рідної мови, використовувати рідне слово як ефективний засіб впливу на дошкільників.

Завдання курсу:

- допомогти студентам глибоко оволодіти літературними нормами української мови, їі словниковим багатством, лексичною системою, граматичною й синтаксичною організаціями рідної мови;

- навчитися використовувати мовні засоби в усному й писемному мовленні 3 урахуванням умінь і завдань комунікації;

- пробудити у студентів серйозний інтерес до предмета задля творчого розв’язання тих чи тих мовленнєвих проблем;

- зміцнити прагнення студентів систематично працювати 3 найновішими літературними й методичними джерелами.

Відповідно до визначених мети та завдань обираємо методи навчання:

- аналіз навчальної літератури з тем курсу;

- реферування й анотування навичок спеціальної літератури;

- пояснювально-ілюстративний;

- дослідницький;

- ділова гра. 
Задля покращення успішності студентів та підвищення якості засвоєння навчального матеріалу з курсу нами була розроблена відповідна система роботи, що передбачає лекційний курс із широким списком основної та додаткової літератури; плани семінарських занять зі списком рекомендованої літератури та пропонованими до виконання вправами й завданнями. До кожного з модулів задля перевірки якості засвоєння матеріалу розроблені тестові завдання, дібрано теми рефератів.

У результаті вивчення навчальної дисципліни студент повинен засвоїти змістові модулі відповідно до розділів мовознавчої науки. Наприклад, змістовий модуль «Фонетика й фонологія. Орфоепія» містить характеристику звука як предмета вивчення фонетики й фонології; системи голосних та приголосних фонем; фонетичних явищ (асиміляція приголосних, дисиміляція приголосних, спрощення в групах приголосних, фонетичні та історичні чергування голосних та приголосних); уявлення про фонетичне членування мовного потоку; склад та основні правила українського складоподілу; наголос, інтонацію, орфоепічні норми сучасної української мови; формує практичні навички фонетичного аналізу слова.

У першому семестрі засвоєння змістового модуля «Графіка й орфографія» спрямовує студентів на формування практичних умінь i навичок правопису через систематизацію, узагальнення відомостей зі шкільного курсу мови та поглибленого вивчення відповідних питань у системі вищої школи. У ході семінарських занять опрацьовуються основні орфограми: правила вживання м'якого знака, апострофа, ненаголошених голосних, правопису префіксів, суфіксів, уживання великої літери, правопису складних слів, слів іншомовного походження тощо.

Опрацювання змістового модуля «Лексикологія і лексикографія» розширює шкільне уявлення студентів-першокурсників про лексичне значення слова, системність словникового складу мови, класифікацію лексики української мови за походженням, уживанням, стилістичним функціонуванням. Систематична робота 3 лексикографічними джерелами-словниками покликана підвищити успішність навчання та якісний потенціал засвоєння майбутніми вихователями української мови.

Багатство української фразеології, класифікацію фразеологічних одиниць, джерела фразеології містить змістовий модуль «Фразеологія».

Рівень успішності та якості знань визначається за кожним модулем.

Підсумковий контроль - написання контрольної роботи.

Оскільки навчальна дисципліна передбачає значну кількість годин на самостійну роботу, нами розроблено іiі систему та перевірку. Індивідуальні завдання передбачають написання рефератів, виступ за його темою та захист.

Другий семестр першого курсу студенти опрацьовують модуль «Морфологія», де повторюють, поглиблюють шкільні знання з системи повнозначних частин мови: іменника, прикметника, числівника, займенника, дієслова та його форм, прислівника (ï морфемної будови, словотвору та відмінювання) та службових слів (прийменника, сполучника, частки).

Підсумковий контроль - написання контрольної роботи та залік за результатами поточної успішності протягом навчального року.

Розподіл балів (загалом 100), які отримують студенти (залік), передбачає: відвідування лекційних занять - 18 балів, підготовка теоретичних питань, виступи на практичних заняттях - 54 бали (максимально 2 бали за одне заняття), написання модульних контрольних робіт - 20 балів (4 бали за кожний модульний контроль); виконання індивідуального завдання - 3 бали, опрацювання модулів самостійної роботи - 5 балів (1 бал на кожний модуль).

Останній змістовий модуль «Синтаксис» опрацьовується у третьому семестрі. 
Систематизуються знання студентів-вихователів дошкільного навчального закладу 3 типології синтаксичного зв'язку у словосполученні, класифікації речень у сучасній українській мові, граматичної будови речення, головних i другорядних членів, проблеми односкладних речень, простого ускладненого речення, класифікації складних речень, подаються основні поняття про текст. Під час опрацювання тих чи тих тем із синтаксису засвоюються відповідні пунктуаційні навички (розділові знаки при однорідних, відокремлених членах речення, звертаннях тощо).

Після завершення курсу передбачена підсумкова форма звітності - іспит. Запропоновані питання до іспиту охоплюють увесь курс «Сучасної української мови 3 практикумом». Вони сприятимуть узагальненню та систематизації знань. На допомогу студентам для вироблення практичних навичок пропонуємо орієнтовні схеми мовних розборів (фонетичний аналіз слова, тексту; лексичний аналіз; морфемний, словотвірний аналізи; морфологічні розбори частин мови; синтаксичний розбір речення).

Розподіл балів (загалом 100), які отримують студенти (екзамен), передбачає: відвідування лекційних занять - 18 балів, підготовка теоретичних питань, виступи на практичних заняттях - 45 балів (максимально 5 балів за одне заняття), написання модульної контрольної роботи - 10 балів; виконання індивідуального завдання 10 балів, опрацювання модуля самостійної роботи - 7 балів; екзамен - 10 балів.

Під час виставлення підсумкової оцінки за навчальну дисципліну заліковий кредит $(100 \%=100$ балів) розподіляється для оцінювання в балах рівня, якості та обсягу знань, умінь та навичок студентів відповідно до таких залікових модулів:

1. Відвідування лекцій $-5 \%$.

2. Участь у практичному занятті (виступ) - 25 \% (передбачається, що максимально за виступ може бути 5 балів, тож студент може виступити не менше 5 разів).

3. Самостійна робота - $30 \%$, зокрема максимальними є такі бали:

- конспект теоретичного матеріалу - $10 \%$;

- виписки, нотатки з рекомендованої методичної літератури, письмові спеціальні вправи - $10 \%$;

- ведення термінологічного словника - $10 \%$.

4. Творча робота - $15 \%$, зокрема максимальними є такі бали:

- тестова контрольна робота - $5 \%$;

- участь у олімпіаді з предмета - $5 \%$;

- аналіз і анотування спеціальної літератури - $5 \%$.

5. Підсумковий модульний контроль $-25 \%$.

Отже, запропоновані нами форми контролю успішності студентів та якості їхніх знань (експрес-опитування, усні повідомлення 3 ключових питань курсу на основі аналізу навчальної літератури, тестування, самостійна робота за завданнями щодо вдосконалення орфографічної й пунктуаційної грамотності студентів, модульний контроль, контрольна робота 3 курсу; вид підсумкового контролю - залік, іспит), уважаємо, сприятимуть досягненню мети, розв'язанню завдань курсу «Сучасна українська мова $з$ практикумом» для студентів спеціальності «дошкільна освіта».

\section{Література}

1. Волков О. І. Система якості вищих навчальних закладів : Теорія і практика / О. І. Волков, Л. М. Віткін, Г. І. Хімічева та ін. - К. : Наук. думка, 2006. - 301 с. 2. Вікторов В. Основні критерії та показники якості освіти / В. Вікторов // Вища освіта України. - 2006. - № 6. - С. 54-59. 3. Лещинський О. Міжнародні моделі оцінки якості інженерної освіти / О. Лещинський // Вища освіта України. - 2007. № 4. - С. 32-35. 4. Зінченко В. О. Якість вищої освіти : чинники впливу / В. О. Зінченко // Освіта Донбасу. - 2011. - № 4. - С. 55-59. 